\title{
REKONSTRUKSI HISTORIS TERHADAP PERAN KHALIFAH AL-HAKIM BIAMRILLAH DULAH FATIMIYAH DALAM PERKEMBANGAN PERPUSTAKAAN DAR AL-HIKMAH DI MESIR TAHUN 996-1021 M
}

\author{
Rima Esni Nurdiana \\ rimaesninurdiana@gmail.com
}

Nurdin Laugu

n.laugu@gmail.com

Ilmu Perpustakaan, Fakultas Adab dan Ilmu Budaya, UIN Sunan Kalijaga

\begin{abstract}
ASTRACT
This research aims to understand the role of al-Hakim Biamrillah in developing of Dar Al-Hikmah library in Egypt during his leadership as Khalifah Daulah Fatimiyah. The research used a qualitative approach based on literature, both primary and secondary sources. This study found a number of important points related to the development of Dar Al-Hikmah library for the role played by the Khalifah al-Hakim. The first role played by al-Hakim is management of Dar AlHikmah library with the appointment of library managers to handle the library collections. The second role is the development of collection through procurement, especially related to the mechanism of purchasing books, both from local and other the countries. The last role concerns the library as a center for the development of science and teaching. As a center of science, this period is marked by the birth of great scientists, such as Ali bin Nu'man and Ibn Killis.
\end{abstract}

Key Words: Khalifah, sejarah, Daulah Fatimiyah

\section{A. PENDAHULUAN}

Pada abad pertengahan, Daulah Fatimiyah dikenal memiliki prestasi gemilang. Syaefudin menjelaskan bahwa Daulah Fatimiyah tersebut lahir pada abad kesepuluh, akhir masa Daulah Abbasiyah bersamaan dengan daulah-daulah kecil lainnya yang mulai melepaskan diri dari kekuasaan Daulah Abbasiyah. Selain itu, ia juga memaparkan bahwa Daulah Fatimiyah mewarisi kemajuan peradaban yang dibangun Umayah dan Abbasiyah. ${ }^{1}$

Philip K. Hitti menjelaskan bahwa Daulah Fatimiyah didirikan di Tunisia tahun 909 M oleh Said ibn Husayn, keturunan kedua pendiri sekte Ismailiyah, seorang Persia bernama Abdullah ibn Maymun. Lebih dalam, Ia memaparkan bahwa Daulah Fatimiyah pada masanya dipimpin oleh 14 khalifah sebagaimana tercantum dalam karya silsilah kekhalifahan Fatimiyah. Adapun Khalifah Al-

\footnotetext{
${ }^{1}$ Syaefudin, Machfud. Dinamika Peradaban Islam: perspektif historis.(Yogyakarta: Pustaka Ilmu, 2013)
} 
Hakim Biamrillah merupakan khalifah keenam yang memimpin Daulah Fatimiyah dalam rentang waktu, tahun 996-1021 M. $^{2}$

Masa pengangkatan Al-Hakim sebagai pemimpin menjadi awal pemerintahan yang tidak stabil. Philip K. Hitti menjelaskan bahwa saat diangkat menjadi khalifah, Al-Hakim masih terlalu muda sehingga kekuasaan sesungguhnya berada di tangan para wazir yang kemudian sering mendapat julukan kebangsawanan "al-malik". Al-Hakim belum memegang kekuasaan penuh. Akan tetapi, secara formalitas ia sudah diangkat menjadi pemimpin menggantikan ayahnya yang telah wafat pada saat Ia masih berusia muda. ${ }^{3}$

Meskipun masih muda saat diangkat menjadi pemimpin, keraguan akan perkembangan perpustakaan sebagaimana dijelaskan Zuhairini ${ }^{4}$ bahwa perpustakaan pada masanya mengalami kejayaan. Bahkan, perpustakaan menjadi salah satu aspek budaya yang penting, selain sebagai tempat belajar dan sumber pengembangan ilmu pengetahuan. Al-Hakim merancang perpustakaan untuk memiliki pengaruh besar dalam memajukan Daulah Fatimiyah pada masa itu.

Pada masa pemeritahannya, Al-Hakim memberikan kontribusi besar dalam perkembangan perpustakaan, khususnya perpustakaan Dar Al-Hikmah (rumah kebijaksanaan) atau Dar al-Ilm (rumah ilmu). Penulis Kitab al-Wulah wa Kitab al-Qudhah dalam Philip K. Hitti memaparkan bahwa Dar Al-Hikmah yang dibangun pada tahun 1005 digunakan sebagai pusat pembelajaran dan penyebaran ajaran Syiah ekstrim. ${ }^{5}$

Selain menghimpun koleksi buku, perpustakaan Dar Al-Hikmah menurut Yatim, lembaga ini juga merupakan pusat pengkajian astronomi, kedokteran, dan ajaran Islam, terutama Syi'ah. ${ }^{6}$ Karim mengemukakan bahwa berbagai macam ilmu keislaman, ilmu astronomi, astrologi, kedokteran, kimia, filsafat, dan ilmuilmu yang lain diajarkan di Dar Al-Hikmah. ${ }^{7}$ Lebih lanjut, Hitti ${ }^{8}$ yang mengutip

\footnotetext{
${ }^{2}$ Hitti, Philip K. History of the Arabs. Terj. Cecep Lukman Yasin dan Dedi Slamet Riyadi. (Jakarta: Serambi Ilmu Semesta, 2002)

${ }^{3}$ Ibid

${ }^{4}$ Zuhairini. Sejarah Pendidikan Islam (Jakarta: Bumi Aksara, 1986)

${ }^{5}$ Hitti, Philip K. History of the Arabs. Terj. Cecep Lukman Yasin dan Dedi Slamet Riyadi. (Jakarta: Serambi Ilmu Semesta, 2008)

${ }^{6}$ Yatim, Badri. Sejarah Peradaban Islam (Jakarta: Raja Grafindo Persada, 2006)

${ }^{7}$ Karim, M. Abdul. Sejarah Pemikiran dan Peradaban Islam (Yogyakarta: Pustaka Book Publisher, 2009)
} 
al-Maqrizi menjelaskan bahwa untuk pembangunan Dar Al-Hikmah ini, AlHakim menyuntikkan sejumlah dana. Di antaranya, sebanyak 257 dinar digunakan untuk menyalin berbagai naskah, memperbaiki buku dan pemeliharaan umum lainnya. Selain itu, gedung perpustakaan Dar Al-Hikmah dengan susunan ruang pertemuan dibangun berdekatan dengan istana kerajaan. Juga, dilakukan pembelajaran yang kurikulumnya meliputi ilmu-ilmu keislaman, astronomi, dan kedokteran.

Hal ini menunjukkan salah satu kontribusi Al-Hakim dalam pemerintahannya terhadap perpustakaan dan ilmu pengetahuan. Tercatat bahwa sosok Al-Hakim dikenal dengan kebijakannya dalam kepemimpinan. Syamsul Munir Amin mengemukakan bahwa tahun-tahun pertama pemerintahannya berada dalam pengaruh seorang gubernur, yaitu Barjuwan. Pemerintahannya ditandai sejumlah tindakan aneh dan kejam. Dalam sepuluh tahun masa pemerintahannya, kaum Yahudi dan Nasrani merasa kehilangan hak-haknya sebagai warga negara sehingga mereka pun mengadakan perlawanan. ${ }^{9}$ Taufiq Abdullah menjelaskan bahwa Al-Hakim kadang-kadang menganjurkan upacara Isma'iliyah dan bahkan membolehkan upacara Sunni yang pernah dilarang ayahnya. Ia juga membakar kota Fustat tanpa sebab yang jelas. ${ }^{10}$ Bahkan dalam Hasan ${ }^{11}$ diungkapkan bahwa ia seringkali menyiksa orang dan menetapkan cara baru dalam pengeksekusian.

Al-Hakim dikenal sebagai sosok raja zalim dari Daulah Fatimiyah, yang dapat dilihat dari kebijakannya yang tidak konsisten, kejam dan tidak toleran selama kememimpinannya. Namun di sisi lain, ia memiliki kontribusi yang tidak sedikit dalam membangun serta mengembangkan perpustakaan Dar Al-Hikmah di Mesir pada saat itu. Atas dasar itu, fenomena perpustakaan Dar Al-Hikmah yang didirikan pada masa itu merupakan hal yang menarik dalam lembaran sejarah. Oleh karena itu, wacana ini menjadi penting untuk dikaji, dipelajari, dan diteliti, khususnya terkait peran Al-Hakim Daulah Fatimiyah dalam perkembangan perpustakaan Dar Al-Hikmah di Mesir tahun 996-1021 M.

\footnotetext{
${ }^{8}$ Hitti, Philip K. History of the Arabs. Terj. Cecep Lukman Yasin dan Dedi Slamet Riyadi. (Jakarta: Serambi Ilmu Semesta, 2002)

${ }^{9}$ Amin, Samsul Munir. Sejarah Peradaban Islam (Jakarta: Amzah, 2009).

${ }^{10}$ Abdullah, Taufiq. Ensiklopedi Tematis Dunia Islam (Jakarta: Ichtiar Baru Van Houve, 2002).

${ }^{11}$ Hasan, Masudul. History of Islam. Vol. 1 (Delhi: Adam Publisher and Distributers, 1995).
} 


\section{METODOLOGI}

Tulisan ini menggunakan metode penelitian sejarah. Menurut Garraghan dalam Abdurrahman, ${ }^{12}$ metode penelitian sejarah merupakan seperangkat aturan dan prinsip sistematis untuk mengumpulkan sumber-sumber sejarah secara efektif, menilainya secara kritis, dan mengajukan sintesis dari hasil-hasil yang dicapai dalam bentuk tulis. Jenis penelitian yang digunakan adalah penelitian perpustakaan, library research, dengan pendekatan sosiologi yang bersifat dekriptif-analitik. Teknik analisis data dilakukan dengan teknik analisis isi melalui teknik BSC (baca, simak, dan catat) sedangkan uji keabsahan datanya menggunakan ketekunan pengamatan dan kecukupan referensial. Sebagai penelitian sejarah, analisis data dilakukan dalam beberapa tahap, seperti dijelaskan Abdurrahman sebagai berikut, antara lain heuristik, kritik, interpretasi, dan historiografi. ${ }^{13}$ Di samping itu, Kuntowijoyo menambahkan satu langkah awal dalam tahapan penelitian sejarah, yakni pemilihan topik penelitian. ${ }^{14}$

\section{Aparatus Konseptual}

Rekonstruksi historis merupakan upaya menguak kembali suatu hal yang berkaitan atau berkenaan dengan sejarah ${ }^{15}$. Rekonstruksi dilakukan terhadap peran Al-Hakim dalam perkembangan perpustakaan Dar Al-Hikmah di Mesir. Hal ini perlu direkonstruksi untuk memahami peristiwa berkenaan peran perpustakaan Dar Al-Hikmah di era kepemimpinan Al-Hakim. Juga, rekontruksi ini penting untuk membangun keutuhan informasi dari berbagai sumber yang terpisahpisah, ${ }^{16}$

Peran merupakan pola perilaku yang melekat pada seseorang. Dalam penelitian ini peran tersebut akan dilihat dalam tiga hal, yakni, pertama, Al-Hakim sebagai seorang pemimpin Daulah Fatimiyah terikat norma-norma yang hidup di masanya. Juga, kesepakatan para khalifah sebelumnya dan masyarakat sekitar. Kedua, Al-Hakim sebagai pemimpin Daulah Fatimiyah memiliki peran penting yang menarik dianalisis, khususnya dalam perkembangan perpustakaan Dar Al-

\footnotetext{
${ }^{12}$ Abdurrahman, Dudung. Metodologi Penelitian Sejarah (Yogyakarta: ArRuzz Media, 2007).

${ }^{13}$ Abdurrahman, Dudung. Metode Penelitian Sejarah (Jakarta: Logos Wacana Ilmu, 1999).

${ }^{14}$ Kuntowijoyo, Pengantar Ilmu Sejarah (Yogyakarta: Yayasan Bentang Budaya, 1995).

${ }^{15}$ Melino, Anton. Kamus Besar Bahasa Indonesia (Jakarta: Balai Pustaka, 1988). Lihat juga Suharso, Ana Retnoningsih. Kamus Besar Bahasa Indonesia (Semarang; Widya Karya, 2014).

${ }^{16}$ Abdurrahman, Dudung. Metodologi Penelitian Sejarah (Yogyakarta: ArRuzz Me, 2007)
} 
Hikmah di Mesir. Ketiga, Perilaku Al-Hakim sebagai seorang pemimpin masyarakat Daulah Fatimiyah menjadi sorotan masyarakat. Oleh karena itu, konsep peran dan/atau peranan sosial menjadi signifikan untuk mengungkapkan andil seseorang yang berkaitan dengan perilaku dalam kehidupan sosialnya. Atas dasar itu, peran Al-Hakim, khususnya dalam perkembangan perpustakaan Dar Al-Hikmah di Mesir akan dapat ditemukan. Hal menarik lainnya adalah Al-Hakim sebagai sosok pemimpin yang kejam melalui kebijakan-kebijakannya tetapi sangat gila akan ilmu pengetahuan hingga ia membangun lembaga ilmu pengetahuan, termasuk perpustakaan. ${ }^{17}$

Sementara, peradaban Islam menurut Maryam dkk. dapat diartikan sebagai perkembangan atau kemajuan kebudayaan Islam pada tingkat kecerdasan akal dalam suatu periode kekuasaan Islam, hasil-hasil yang dicapai umat Islam berupa bidang kesusatraan, ilmu pengetahuan, dan kesenian. Peradaban Islam tersebut sangat berpengaruh terhadap kemajuan politik atau kekuasaan Islam yang berperan melindungi pandangan hidup Islam terutama dalam hubungannya dengan ibadah, penggunaan bahasa, dan adat istiadat dalam masyarakat. Peradaban Islam tersebut telah dicapai melalui berbagi bidang. Adapun latar belakang munculnya perpustakaan Islam pada masa kepemiminan Islam merupakan suatu tempat yang digunakan untuk aktifitas belajar mengajar dan menghimpun beragam koleksi tulis yang bisa digunakan dalam menunjang proses belajar mengajar tersebut. ${ }^{18}$

Manajemen perpustakaan merupakan pengelolaan perpustakaan berdasarkan teori dan prinsip manajemen dengan pemanfaatan sumber daya manusia, informasi, sistem, sumber dana sesuai fungsi manajemen, peran, dan keahlian. Pengembangan koleksi merupakan proses membangun koleksi di perpustakaan secara sistematis untuk memenuhi kebutuhan pemustaka dalam pembelajaran, pengajaran, penelitian, rekreasi, dan memudahkan pemustaka dalam proses temu kembali informasi (information retrieval) di perpustakaan.

${ }^{17}$ Burke, Peter. Sejarah dan Teori-teori Sosial. Terj. Mestika Zed dan Zulhami (Jakarta: Yayasan Obor Indonesia, 2001); Cohen, Bruce J. Sosiologi Suatu Pengantar. (Jakarta: Rineka Cipta, 1992); Soekanto, Suryono. Sosiologi: Suatu Pengantar (Jakarta: Raja Grafindo Persada, 1985).

${ }^{18}$ Maryam, Siti dkk. Sejarah Kebudayaan Islam. (Yogyakarta: Pokja Akademik UIN Sunan Kalijaga, 2004). 
Dalam tahapan kegiatan pengembangan koleksi, penjelasan akan difokuskan pada kebijakan pengembangan koleksi dan pengadaan koleksi. ${ }^{19}$

\section{HASIL DAN PEMBAHASAN}

\subsection{Perhatian Al-Hakim terhadap Perpustakaan}

Samsuddin memaparkan bahwa perjalanan sejarah Islam mengalami pasang surut yang dapat dilihat dari fase pertumbuhan, perkembangan, kejayaan, dan kemunduran. Pada tahap perkembangan tersebut, nuansa renaisans kejayaan Islam merebak dalam segala lini kehidupan, di antaranya bidang sains atau ilmu pengetahuan. Hal tersebut ditandai dengan hadirnya lembaga-lembaga pendidikan Islam yang mempunyai standar mutu dan melahirkan intelektual Muslim. Salah satunya Dar Al-Hikmah. Lembaga ini merupakan simbol Islam yang sangat dibanggakan karena memberikan arti penting bagi perkembangan ilmu pengetahuan. $^{20}$

Syalabi dalam Rifai $^{21}$ menjelaskan bahwa pertumbuhan dan perkembangan perpustakaan dunia Islam masa klasik tidak lepas dari usaha pengembangan ilmu pengetahuan. Pada masa silam, perpustakaan menjadi salah satu sarana penting bagi umat Islam untuk menyiarkan ilmu pengetahuan. Hal ini menunjukkan bahwa saat itu perkembangan dan penyebaran ilmu pengetahuan mulai marak, seperti berdirinya lembaga-lembaga ilmu pengetahuan yang maju. Demikian juga, saat itu budaya tulis menulis telah berkembang pesat. Banyak penulis ternama yang lahir pada masa itu, seperti Al-Khawarizmi dan Ibnu Sina. Kemajuan tulis menulis tersebut menumbuhkan kesadaran masyarakat terhadap ilmu pengetahuan dan membentuk masyarakat yang literate, dalam pengertian mereka mampu menyerap ilmu pengetahuan serta mengetahui bagaimana cara memperoleh, memilih, dan mengaplikasikan hasil pemahaman tersebut. Ini

\footnotetext{
${ }^{19}$ Lasa Hs. Kamus Kepustakawanan Indonesia (Yogyakarta: Pustaka Book Publisher, 2009); Qalyubi, Syihabuddin dkk. Dasar Ilmu Perpustakaan dan Informasi (Yogyakarta: Jurusan Ilmu Perpustakaan dan Informasi Fakultas Adab dan Ilmu Budaya UIN Sunan Kalijaga, 2007); Sutarno NS. Manajemen Perpustakaan: suatu pendekatan praktik (Jakarta: Sagung Seto, 2006)

${ }^{20}$ Samsuddin. "Institusi Pendidikan Islam (eksistensi perpustakaan darul himah / darul ilmi dan upaya pengembangannya dalam konteks kekinian", dalam Jurnal Al-Kuttab, Vol.1, No. 1 (Juni 2013). Diakses dalam ejournal.perpustakaanstainpsp.net>pdf_1 pada tanggal 17 Juli 2017 pukul 13.28 WIB.

${ }^{21}$ Rifai, Agus. Perpustakaan Islam: konsep, sejarah, dan kontribusinya dalam membangun peradaban Islam masa klasik (Jakarta: Rajawali Press, 2013).
} 
menjadi bukti nyata bahwa masa silam meninggalkan jejak kemajuan ilmu pengetahuan masayarakat Islam yang tak tertandingi masa itu.

Saat itu Al-Hakim juga memiliki andil besar terhadap perkembangan ilmu pengetahuan. Perpustakaan Dar Al-Hikmah yang dikembangkannya menjadi bagian penting dari perkembangan ilmu pengetahuan tersebut. Upaya ini dilakukan melalui pengumpulan hasil karya ilmu pengetahuan dari berbagai tempat. Inilah salah satu perhatiannya yang amat besar yang merupakan kontribusi terhadap perkembangan perpustakaan pada masa itu. Ia juga menyediakan guru untuk mengajar di perpustakaan tersebut. Selain perkembangan ilmu pengetahuan, Rifai ${ }^{22}$ menyatakan bahwa saat itu juga terdapat waraq (penyalin atau juru tulis) yang bertugas menyalin buku. Waraq pada masa itu menjadi profesi tersendiri yang berbeda dari penulis atau pengarang buku. Waraq memiliki peran yang cukup penting, seperti penulis itu sendiri. Saat mereka ingin membangun perpustakaan, waraq mengambil peran sebagi penyalin buku-buku karya penulis tersebut.

Perkembangan ilmu pengetahuan pada tahun 992-1021 M tidak lepas dari sosok Al-Hakim yang meskipun perilakunya dikenal dingin dan kejam. Namun di sisi lain, menurut Rahim, ${ }^{23}$ Al-Hakim merupakan sosok yang sangat murah hati dan sangat memberikan kebebasan dalam pembelajaran dan ilmu pengetahuan. Murah hati disini tampak dari sikap Al-Hakim yang rela memberikan harta pribadinya untuk mendanai kemajuan Perpustakaan Dar Al-Hikmah. Kecintaan Al-Hakim terhadap ilmu pengetahuan tersebut melahirkan lembaga-lembaga ilmu pengetahuan yang mampu membawa nama besar bagi Daulah Fatimiyah. Lembaga-lembaga tersebut, di antaranya, masjid, akademi, dan observatorium. Masjid pada masa itu tidak hanya digunakan sebagai tempat untuk beribadah tetapi juga digunakan sebagai tempat untuk menyebarkan ilmu pengetahuan. Imamuddin dalam $\mathrm{Nata}^{24}$ mengemukakan bahwa masjid merupakan tempat belajar umat Islam melalui proses belajar kelompok. Hal tersebut diterapkan agar

\footnotetext{
${ }^{22}$ Ibid.

${ }^{23}$ Rahim, A. Islamic History (Delhi: Royal Publisher and Distributors, 1992).

${ }^{24}$ Nata, Abuddin. Sejarah Pendidikan Islam (Jakarta: Rajawali Pers, 2004).
} 
umat Islam yang tengah belajar tidak mengganggu umat Islam lain yang tengah beribadah.

Adapun akademi yang dibangun Al-Hakim adalah perpustakaan Dar AlHikmah. Perpustakaan tersebut merupakan salah satu lembaga ilmu pengetahuan terkemuka saat itu. Perpustakaan ini tidak hanya berfungsi sebagai penyimpan koleksi buku, naskah, dan manuskrip, tetapi juga sebagai akademi dalam pengertian luas. Perpustakaan Dar Al-Hikmah setara dengan lembaga akademi lainnya, seperti Baitul Hikmah di Baghdad dan Grand Mosque di Codova. perpustakaan Dar Al-Hikmah merupakan institusi pendidikan meskipun tujuannya yang paling dominan adalah untuk menyebarkan ajaran Syieeah. Lembaga ilmu pengetahuan lainnya dibangun Al-Hakim adalah sebuah observatorium. Hitti menjelaskan bahwa Al-Hakim sangat tertarik pada perhitungan astronomi. Oleh karena itu, ia membangun sebuah observatorium di Mukatam dan membuat astorable sepanjang tiga jengkal yang dibangun diatas dua menara untuk mengukur zodiak. Observatorium tersebut merupakan tempat yang digunakan untuk melakukan pembelajaran mengenai astronomi. ${ }^{25}$

Selain itu, kecintaan Al-Hakim terhadap ilmu pengetahuan membawa angin segar bagi kemajuan ilmu pengetahuan. Pada masanya, Al-Hakim memberikan perhatian serius kepada para intelektual yang memiliki keahlian dalam berbagai bidang ilmu pengetahuan. Jadi, wajar jika pada masa Al-Hakim lahir beberapa ilmuwan dari beberapa bidang. Seperti dijelaskan $\mathrm{Hitti}^{26}$ bahwa masa Al-Hakim ditemukan beberapa ahli dalam bidang astronomi, ilmu fisika dan optik, yakni Ali ibn Yunus, ${ }^{27}$ Abu Ali al-Hasan ibn al-Haitsam. Dari para ilmuan tersebut lahir berbagai karya penting, seperti Sij al-Akbar Al-Hakimi, Kitab alManazhir (ilmu optik) dan al-Muntakhab fi 'ilaj al-'ayn (penyembuhan mata). Perpustakaan Dar Al-Hikmah sebagai lembaga penyebaran ilmu pengetahuan yang yang dibangunnya bukan saja digunakan sebagai tempat untuk menyimpan

\footnotetext{
${ }^{25}$ Hitti, Philip K. History of the Arabs. Terj. Cecep Lukman Yasin dan Dedi Slamet Riyadi (Jakarta: Serambi Ilmu Semesta, 2002)

${ }^{26}$ Ibid, hlm. 802.

${ }^{27}$ Ali Ibn Yunus adalah seorang fisikawan dan astronom handal, di samping juga seorang ahli matematika yang berbakat. Sayyed Hossein Nasr (1992) menyebut bahwa Ali Ibn Yunus adalah orang pertama yang menelaah gerak isometris sebuah pendulum, sebuah penelitian yang kemudian menuju kepada konstruksi jam mekanis.
} 
beragam koleksi buku dan tempat untuk mengajarkan ajaran Syi ${ }^{i e}$ ah tetapi juga digunakan sebagai tempat berkumpul para ahli fikih, para ahli nahwu dan bahasa. ${ }^{28}$ Para dokter dan ahli astronomi berkumpul dan memanfaatkan perpustakaan yang tidak sekedar tempat belajar dan membaca buku-buku tetapi juga melakukan pengkajian dan penyalinan kitab-kitab serta melakukan ceramah dan diskusi tentang berbagai bidang ilmu pengetahuan.

\subsection{Peran Al-Hakim terhadap Perpustakaan Dar Al-Hikmah}

Berbicara mengenai peran Al-Hakim dalam perkembangan perpustakaan Dar Al-Hikmah tidak lepas dari tahapan manajemen perpustakaan yang mampu dibangunnya pada saat itu. Manajemen perpustakaan menurut Qalyubi terdiri dari perencanaan, pengorganisasian, kepemimpinan, dan pengawasan. ${ }^{29}$ Sementara, Lasa Hs menjelaskan bahwa dalam perencanaan perpustakaan, langkah awal yang harus dilakukan adalah penetapan visi, misi, tujuan, identifikasi kekuatan dan kelemahan, dan memahami peluang dan ancaman. ${ }^{30}$ Jika teori tersebut diterapkan dalam sejarah perkembangan perpustakaan Dar Al-Hikmah, maka peran AlHakim terhadap perpustakaan tersebut dapat disimpulkan bahwa ia telah mencapai prinsip distribusi informasi dalam kerangka pengorganisasian informasi yang meskipun khusus pada penyebaran paham Syi'ah ekstrem.

Dalam tahap pengorganisasian tersebut, secara rinci peran Al-Hakim dijelaskan dalam tiga capaian, yakni pengelolaan perpustakaan, pengembangan koleksi, dan pemanfaatan perpustakaan sebagai wadah untuk keilmuan dan pembelajaran.

\section{Pengelolaan Perpustakaan}

Pada masa Al-Hakim, perpustakaan Dar Al-Hikmah memiliki pegawai yang mengelola perpustakaan dengan baik. Hal tersebut dijelaskan Hamka dalam Rifai bahwa perpustakaan Dar Al-Hikmah mempunyai pegawai yang secara khusus dipercaya untuk mengelola perpustakaan tersebut. Adapun struktur organisasi di perpustakaan Dar Al-Hikmah ini terdiri dari kepala perpustakaan dan staf perpustakaan. Selain kepala dan staf perpustakaan yang secara struktural

\footnotetext{
${ }^{28}$ Rifai, AgusPerpustakaan Islam: konsep, sejarah, dan kontribusinya dalam membangun peradaban Islam masa klasik (Jakarta: Rajawali Press, 2013).

${ }^{29}$ Qalyubi, Syihabuddin dkk. Dasar Ilmu Perpustakaan dan Informasi. Yogyakarta: Jurusan Ilmu Perpustakaan dan Informasi Fakultas Adab dan Ilmu Budaya UIN Sunan Kalijaga, 2007).

${ }^{30}$ Lasa Hs. Kamus Kepustakawanan Indonesia (Yogyakarta: Pustaka Book Publisher, 2009:23) 
bertanggung jawab dalam pengelolaan perpustakaan, ada beberapa pegawai lainnya yang turut serta mengelola perpustakaan. ${ }^{31}$ Hal ini dijelaskan al-Maqrizi dalam Syalabi bahwa perpustakaan Dar Al-Hikmah dilengkapi dengan alat-alat tulis, pegawai, khadam dan/atau pesuruh yang diberi tugas menjaga dan berkhidmat kepada perpustakaan. Senada dengan hal tersebut, ia juga menerangkan bahwa perpustakaan Dar Al-Hikmah memiliki banyak pemimpin, asisten, dan pelayan. ${ }^{32}$

Berbicara mengenai pesuruh (pembantu) di perpustakaan, Syalabi menerangkan bahwa kedudukan pembantu di perpustakaan tidak setinggi kedudukan pemimpin perpustakaan, tetapi tidak di level pegawai kebersihan. Seorang pembantu perpustakaan harus mengetahui judul-judul buku dan tempatnya, tetapi tidak sampai pada taraf ilmiah karena tidak mengetahui ide-ide buku itu. Mengetahui ide buku adalah kewajiban pemimpin perpustakaan. Dengan mengetahui isi buku itu, para pemimpin dapat menyusun dan memilih buku di tempat yang seharusnya. ${ }^{3233}$

Demikian juga, berdirinya perpustakaan Dar Al-Hikmah dirancang dengan matang oleh Al-Hakim. Beliau membuka perpustakaan untuk umum setelah perpustakaan memiliki dekorasi dan pegawai yang lengkap. Hal ini dapat dilihat dari penjelasan al-Maqrizi dalam Syalabi bahwa perpustakaan Dar AlHikmah di Kairo baru dibuka untuk umum setelah selesai dihias, pintu-pintu, dan jendela-jendela diberi kain pintu, para pegawai, pekerja, dan khadam akan mengendalikan perpustakaan dan melayani para pengunjung. Fenomena ini merupakan suatu bentuk perancangan yang matang dalam pengelolaan perpustakaan. Seperti itulah, Al-Hakim memperhatikan dengan baik pegawai pengelola perpustakaan. ${ }^{34}$

Para pegawai perpustakaan Dar Al-Hikmah bekerja sesuai dengan tugasnya masing-masing. Kepala dan staf perpustakaan lebih konsen dalam mengelola segala hal yang berkaitan dengan perpustakaan. Berikut beberapa tugas kepala dan staf perpustakaan Dar Al-Hikmah yang secara teknis dilakukan berdasarkan analisis peneliti:

a. Shelving. Meskipun belum ditemukan sumber data mengenai shelving (penyusunan buku di rak) buku yang digunakan perpustakaan Dar AlHikmah, Syalabi ${ }^{35}$ menjelaskan bahwa kaum Muslim di abad pertengahan belum mengenal cara penyusunan buku di rak seperti saat ini. Buku hanya disusun dengan meletakkannya secara berdiri. Syalabi mengutip pendapat

${ }^{31}$ Rifai, Agus. Perpustakaan Islam: konsep, sejarah, dan kontribusinya dalam membangun peradaban Islam masa klasik (Jakarta: Rajawali Press, 2003).

${ }^{32}$ Syalabi, Ahmad. Sejarah Pendidikan Islam (Jakarta: Bulan Bintang, 1973).

${ }^{32}$ Ibid.

${ }^{33}$ Ibid

${ }^{34}$ Ibid.

${ }^{35}$ Ibid. 
Djama'ah yang menerangkan bahwa pada masa itu buku-buku disusun dengan cara buku-buku yang besar jangan diletakkan di atas yang kecil agar tidak runtuh.

b. Klasifikasi dan Katalogisasi. Syalabi menerangkan bahwa pada masa itu buku disusun dengan cara ditidurkan sehingga nama pengarang tidak dituliskan di punggung buku tetapi dituliskan di kaki buku. Bila buku-buku disusun bertumpukan dalam rak, maka nama pengarang diletakkan di sebelah luar agar orang mudah mencarinya. Perpustakaan Dar Al-Hikmah menggunakan sistem klasifikasi Perpustakaan Fatimiyah. Informasi didasarkan pada paparan Syalabi bahwa masing-masing pintu kamar (ruangan) ditempel daftar buku yang berisi nama buku dan nomornya. ${ }^{36}$

c. Penurun (penyalin buku). Syalabi menjelaskan bahwa kegiatan menurun buku-buku di Mesir sangat besar. Perpustakaan Dar Al-Hikmah pada masa itu memberikan tugas kepada sejumlah penurun untuk melengkapi koleksi bukubuku yang belum dimiliki perpustakaan. Selanjutnya, ia juga menjelaskan bahwa di rumah Ja'qub Ibnu Killis ${ }^{37}$ ada beberapa orang yang pekerjaannya menurun al-Qur'an, hadis, fiqh, kesusastraan, dan ilmu kedokteran. ${ }^{38}$

d. Penjilidan. Hitti menerangkan bahwa seni penjilidan buku di dunia Islam yang paling pertama dikenal datang dari Mesir sekitar abad kedelapan atau sembilan. Teknik dan dekorasi yang mereka miliki bersanding indah dengan daya tarik seni penjilidan Koptik yang lebih dulu muncul dan masih menjadi patokan keahlian menjilid. Setelah mazhab Mesir dalam seni penjilidan berkembang, teknik menghiasi sampul buku dengan alat dan stempel menjadi teknik yang banyak dipakai oleh para pengrajin yang menggunakan kulit. Dari hal tersebut, tentunya dalam proses penjilidan di Mesir sudah memiliki patokan yang jelas. ${ }^{39}$

Samsuddin menngungkapkan bahwa manajemen operasional perpustakaan Dar Al-Hikmah pada masa itu dapat digolongkan pada taraf relatif bagus yang ditandai dengan berdirinya bangunan-bangunan khusus, inventarisasi ratusan bahkan ribuan buku. Selain itu, acara seremonial juga ramai melalui penyediaan kamar musik dengan tujuan untuk melepaskan lelah setelah terkuras tenaga membaca yang mengasyikkan. ${ }^{40}$

\footnotetext{
${ }^{36}$ Ibid.

37 Ja'qub Ibnu Killis (Yaqub Ibn Killis) yakni wazir pada zaman Mu'îz dan al-'Azîz yang diberi mandat oleh al-'Azîz sebagai pelindung ilmu pengetahuan. Lihat M. Abdul Karim, Sejarah Pemikiran dan Peradaban Islam (Yogyakarta: Bagaskara, 2012), hlm. 201. 38

${ }^{39}$ Hitti, Philip K. History of the Arabs. Terj. Cecep Lukman Yasin dan Dedi Slamet Riyadi (Jakarta: Serambi Ilmu Semesta, 2002).

${ }^{40}$ Samsuddin. "Institusi Pendidikan Islam (eksistensi perpustakaan darul himah / darul ilmi dan upaya pengembangannya dalam konteks kekinian", dalam Jurnal Al-Kuttab, Vol.1, No. 1 (Juni
} 


\section{Pengembangan Koleksi}

Perpustakaan Dar Al-Hikmah yang memiliki berbagai bidang pengembangan ilmu membutuhkan pengembangan koleksi yang baik. Pengembangan koleksi sangat penting dalam memenuhi kebutuhan perpustakaan. Pengelolaan perpustakaan dilakukan dengan baik sebagai respon terhadap kebutuhan koleksi perpustakaan Dar Al-Hikmah untuk mewujudkan koleksi yang lengkap. Terkait pemenuhan kebutuhan perpustakaan tersebut, dijelaskan Zahid dan Pianto dalam Imamuddin bahwa Al-Hakim secara suka rela mewakafkan sebagian harta pribadinya. Bahkan, al-Maqrizi dalam Imamuddin juga menjelaskan suntikan dana Al-Hakim sebanyak 275 dinar setiap tahunnya. Rincian dana tersebut di antaranya gaji pustakawan 48 dinar, gaji pegawai lainnya 15 dinar, kertas untuk menyalin 90 dinar, kertas, pena, dan tinta 12 dinar, anyaman abbadani 10 dinar, air 12 dinar, perbaikan tirai 1 dinar, perbaikan buku robek dan rusak 12 dinar, tirai musim dingin 5 dinar, karpet musim dingin 4 dinar, dan sisanya untuk keperluan lainnya. ${ }^{41}$

Penjelasan di atas menunjukkan perhatian besar Al-Hakim dengan mengeluarkan biaya setiap tahunnya untuk perpustakaan. Utamanya dalam anggaran kertas yang mengeluarkan biaya sampai 90 dinar. Syalabi menjelaskan bahwa pengeluaran sebanyak 90 dinar tersebut boleh jadi termasuk gaji penurun sehingga wajar jika biaya yang dikeluarkan paling banyak. Hal ini dikarenakan tugas penurun ialah menyalin buku yang tidak sedikit jumlahnya, di samping pekerjaannya menurun sekaligus menjilid. Hal tersebut juga dijelaskan lebih lanjut yang mengutip dari al-Fihris dkk, yakni berbicara tentang penurun berarti juga berbicara mengenai para penjilid. ${ }^{42}$

Dari sini tampak bahwa Al-Hakim membangun perpustakaan dengan segala perlengkapannya yang sangat baik, terutama dalam koleksi buku-buku di perpustakaan Dar Al-Hikmah yang terdiri dari berbagai bidang pengembangan ilmu pengetahuan. Ia membangun perpustakaan Dar Al-Hikmah dengan koleksi,

2013). Diakses dalam ejournal.perpustakaanstainpsp.net>pdf_1 pada tanggal 17 Juli 2017 pukul 13.28 WIB.

${ }^{41}$ Imamuddin, S.M. Some Leading Muslim Libraries of the World (Dhaka: Islamic Foundation Bangladesh, 1983).

${ }^{42}$ Syalabi, Ahmad. Sejarah Pendidikan Islam (Jakarta: Bulan Bintang, 1973). 
baik buku, kitab ataupun manuskrip yang tidak sedikit jumlahnya. Hal ini dijelaskan al-Siba'i dalam Rifai. Dari segi fasilitas perpustakaan, Al-Hakim membangun perpustakaan yang lebih dari 40 ruang dan salah satu di antaranya berisi 18.000 buku tentang ilmu-ilmu kuno. Menurut Nakosten dalam Rifa'i, perpustakaan Dar Al-Hikmah pada masa itu memiliki koleksi buku sekitar 1.600.000 volume. Adapun sumber lainnya menyebutkan jumlah koleksi buku tersebut lebih dari 2 juta eksemplar. ${ }^{43}$

Senada dengan penjelasan di atas, al-Maqrizi dalam Syalabi memaparkan bahwa khazanah-khazanah Amirul Mu'minin Al-Hakim berupa kitab dan manuskrip terdapat dalam berbagai bidang ilmu pengetahuan dan sastra. Pada saat itu, kekhalifahan mana pun belum pernah ada yang mengumpulkan sebanyak kitab dan manuskrip yang dikumpulkan Al-Hakim. Meskipun mereka sudah mengumpulkan ratusan naskah, jika ia mengetahui bahwa masih ada naskah untuk perpustakaan, ia bersedia untuk membeli naskah tersebut dengan harga berapa pun untuk perpustakaan. Hal ini bukan suatu masalah baginya sepanjang naskah itu dapat mereka miliki untuk menjadi koleksi perpustakaan. Oleh karena itu, fenomena tersebut menjadi keistimewaan Daulah Fatimiyah, yakni upaya menumpahkan perhatian untuk mengumpulkan semua naskah dari berbagai macam buku. ${ }^{44}$

Dari paparan di atas dapat diketahui bahwa salah satu upaya dalam pengembangan koleksi yang diterapkan perpustakaan Dar Al-Hikmah, yakni mengadakan pembelian koleksi. Pengembangan koleksi ini penting untuk dilakukan dalam sebuah perpustakaan. Berdasarkan paparan Yulia (2009), pengembangan koleksi merupakan suatu proses universal untuk perpustakaan karena setiap perpustakaan akan membangun koleksi yang kuat demi kepentingan penggunanya. ${ }^{45}$ Selain itu, Rifai (2013) menjelaskan bahwa buku memang masih

\footnotetext{
${ }^{43}$ Rifai, Agus. Perpustakaan Islam: konsep, sejarah, dan kontribusinya dalam membangun peradaban Islam masa klasik (Jakarta: Rajawali Press, 2003).

${ }^{44}$ Syalabi, Ahmad. Sejarah Pendidikan Islam (Jakarta: Bulan Bintang, 1973).

${ }^{45}$ Yulia, Yuyu dan Janti G. Sujana. Materi Pokok Pengembangan Koleksi (Jakarta: Universitas Terbuka, 2009).
} 
merupakan salah satu koleksi utama di berbagai perpustakaan. Hal ini terutama terdapat dalam sistem perpustakaan konvesional. ${ }^{46}$

Berkaitan dengan penjabaran di atas, menurut Evans dalam Yulia ${ }^{47}$ (2009), proses pengembangan koleksi secara terperinci terdiri dari 7 komponen kegiatan, yakni: 1) menentukan kebijakan umum pengembangan koleksi, 2) menentukan kewenangan, tugas, dan tanggung jawab semua unsur yang terlibat dalam pengembangan koleksi, 3) mengidentifikasi kebutuhan pengguna, 4) memilih dan mengadakan bahan pustaka, 5) merawat bahan pustaka, 6) menyiangi bahan pustaka, dan 7) mengevaluasi koleksi. Jika merujuk pada konsep pengembangan koleksi tersebut, maka perpustakaan masa Al-Hakim sudah menerapkan dua proses pengembangan koleksi sebagai berikut:

a. Pengadaan koleksi. Jenis pengadaan koleksi yang dilakukan pada masa AlHakim adalah melalui pembelian. Hal ini dijelaskan Imamuddin $^{48}$ (1983) yang mengutip Kitab al-'Asa bahwa Al-Hakim mengutus stafnya untuk mencari koleksi yang belum dimiliki dengan melakukan pembelian koleksi sampai ke luar wilayah kekuasaan Daulah Fatimiyah.

b. Perawatan koleksi. Perawatan koleksi perpustakaan Dar Al-Hikmah dapat dilihat dari rincian anggaran dana perpustakaan setiap tahunnya sebagaimana paparan al-Maqrizi dalam Imamuddin ${ }^{49}$ bahwa dana sebanyak 12 dinar dari anggaran 275 dinar setiap tahunnya digunakan untuk keperluan perbaikan buku robek dan rusak. Dari keterangan tersebut dapat diketahui bahwa di perpustakaan Dar Al-Hikmah, petugas juga melakukan perbaikan buku-buku yang rusak.

Selain itu, proses pengembangan koleksi lainnya juga dapat dilihat dalam bentuk sikap Al-Hakim yang atentif mengutamakan kelengkapan koleksi di perpustakaan Dar Al-Hikmah. Misalnya, kerjasama dikembangkan untuk mewujudkan koleksi yang lengkap di perpustakaan. Imamuddin yang mengutip

\footnotetext{
${ }^{46}$ Rifai, Agus. Perpustakaan Islam: konsep, sejarah, dan kontribusinya dalam membangun peradaban Islam masa klasik (Jakarta: Rajawali Press, 2003).

${ }^{47}$ Yulia, Yuyu dan Janti G. Sujana. Materi Pokok Pengembangan Koleksi (Jakarta: Universitas Terbuka, 2009).

${ }^{48}$ Imamuddin, S.M. Some Leading Muslim Libraries of the World (Dhaka: Islamic Foundation Bangladesh, 1983).

${ }^{49}$ Ibid.
} 
Kitab al-'Asa menyatakan bahwa perpustakaan Dar Al-Hikmah merupakan perpustakaan dengan koleksi terlengkap dalam berbagai bidang ilmu. ${ }^{50}$ Sejalan dengan itu, Mahasnah menyebutkan bahwa kelengkapan koleksi juga dilakukan dengan cara mengangkut buku-buku dari berbagai negeri ke perpustakaan Dar AlHikmah. Paparan ini tampak jelas bahwa Al-Hakim sangat memperhatikan kelengkapan koleksi di perpustakaan Dar Al-Hikmah. ${ }^{51}$

Hal tersebut sejalan dengan penjelasan Zahid dan Pinto dalam Imamuddin bahwa perpustakaan Dar Al-Hikmah berisi 600.000-100.000 volume koleksi. Mislanya, 2.400 di antaranya merupakan koleksi al-Qur'an dan 18.000 koleksi naskah kuno. Adapun sisa koleksi lainnya merupakan koleksi tentang hukum, bahasa, retorika, sejarah, biografi, astronomi, dan kimia. Semua koleksi tersebut memiliki beberapa salinan yang sama (eksemplar), di antaranya ada lebih dari 20 salinan buku Tarikh Tabari, ada lebih dari 30 salinan Kitab al-'Ayn dan 100 salinan Kitab al-Jamhirah li ibn Daridah. Koleksi tersebut disimpan di rak dengan keamanan sistem buka-tutup rak menggunakan kunci. ${ }^{52}$

Selain itu, menurut paparan Fakhrurazi dalam Samsuddin, ${ }^{53}$ banyaknya buku-buku yang terdapat di perpustakaan Dar Al-Hikmah adalah atas perintah AlHakim untuk mengangkut buku-buku tersebut dari istananya. Buku-buku yang tidak sedikit jumlahnya ini terdiri dari kitab-kitab sastra, ilmu kedokteran, ilmu pasti, serta manuskrip yang belum pernah dimiliki raja-raja lainnya. Meskipun demikian, Al-Hakim memiliki kebijakan bahwa siapapun boleh memasuki perpustakaan Dar Al-Hikmah, baik ingin belajar, membaca, melihat-melihat saja, maupun ingin menyalin ilmu-ilmu yang ada di sana dalam kertas. Bahkan, di perpustakaan Dar Al-Hikmah juga disediakan kertas dan tinta untuk menulis tanpa dikenakan biaya.

\footnotetext{
${ }^{50}$ Ibid.

${ }^{51}$ Mahasnah, Muhammad Husain. Pengantar Studi Sejarah Peradaban Islam. Jakarta: Pustaka al Kautsar, 2016).

${ }^{52}$ Imamuddin, S.M. Some Leading Muslim Libraries of the World (Dhaka: Islamic Foundation Bangladesh, 1983).

${ }^{53}$ Samsuddin. "Institusi Pendidikan Islam (eksistensi perpustakaan darul himah / darul ilmi dan upaya pengembangannya dalam konteks kekinian", dalam Jurnal Al-Kuttab, Vol.1, No. 1 (Juni 2013). Diakses dalam ejournal.perpustakaanstainpsp.net>pdf_1 pada tanggal 17 Juli 2017 pukul 13.28 WIB.
} 


\section{Pusat Keilmuan dan Pembelajaran}

Secara umum, pendirian perpustakaan pada masa kemajuan dunia Islam merupakan salah satu sarana penyebaran ilmu pengetahuan. Hal ini dijelaskan Syalabi $^{54}$ bahwa berdirinya perpustakaan merupakan suatu cara yang ditempuh oleh orang-orang dahulu untuk menyiarkan ilmu pengetahuan. Pada masa tersebut, buku-buku sangat mahal harganya karena ditulis dengan tangan. Oleh karena itu, hanya orang-orang kaya saja yang dapat membeli dan mempunyai buku. Perpustakaan didirikan sebagai sarana untuk belajar dalam rangka menyiarkan ilmu pengetahuan. Sama halnya pada masa Daulah Fatimiyah juga dibangun sebuah perpustakaan sebagai sarana untuk menyebarkan ilmu pengetahuan. Menurut Hamka dalam Rifai, Al-Hakim sebagai khalifah ke-6 Daulah Fatimiyah mendirikan perpustakaan Dar Al-Hikmah di Kairo, Mesir. Secara rinci, al-Siba'i menyebutkan bahwa perpustakaan Dar Al-Hikmah dibuka tanggal 10 Jumadil Akhir tahun $395 \mathrm{H}$ setelah dilengkapi berbagai perabotan dan dekorasi yang mewah. Shadily dalam Samsuddin memaparkan bahwa perpustakaan Dar Al-Hikmah merupakan tempat untuk mempelajari filsafat dan ilmu pengetahuan Romawi dan ilmu keislaman. ${ }^{55}$

Penjelasan tersebut menerangkan bahwa pembangunan perpustakaan Dar Al-Hikmah sebagai sarana untuk penyebaran ilmu pengetahuan merupakan bukti adanya kemajuan dalam perkembangan ilmu pengetahuan Daulah Fatimiyah. Kemajuan tersebut ditandai adanya perpustakaan Dar Al-Hikmah sebagai pusat keilmuan Daulah Fatimiyah. Sebagai salah satu bukti, Hitti ${ }^{56}$ menjelaskan situasi ini, yakni seorang dokter yang sangat terkenal bernama Muhammad al-Tamim yang lahir di Yerussalem berpindah ke Mesir sekitar tahun 970 M. Terlepas dari penjelasan Mackensen ${ }^{57}$ bahwa Al-Hakim mendirikan perpustakaan sebagai lembaga ilmu pengetahuan sekaligus menjadi pusat propaganda Ismaili yang mencerminkan intelektual dan kepentingan religius dan ambisi para khalifah

\footnotetext{
${ }^{54}$ Syalabi, Ahmad. Sejarah Pendidikan Islam (Jakarta: Bulan Bintang, 1973).

55 Rifai, Agus. Perpustakaan Islam: konsep, sejarah, dan kontribusinya dalam membangun peradaban Islam masa klasik (Jakarta: Rajawali Press, 2003).

${ }^{56}$ Hitti, Philip K. History of the Arabs. Terj. Cecep Lukman Yasin dan Dedi Slamet Riyadi. (Jakarta: PT Serambi Ilmu Semesta, 2008).

${ }^{57}$ Mackensen, Ruth Stellhorn. "Background of the History of Muslim Libraries". dalam The American Journal of Semitic Language and Literatures, Vol. 52 (Oktober-Juli), 1936.
} 
Daulah Fatimiyah. Hal tersebut tidak mengurangi kontribusi Al-Hakim dalam perpustakaan Dar Al-Hikmah sepanjang penyebaran ilmu pengetahuan melalui perpustakaan Dar Al-Hikmah.

Tidak berhenti sampai pada penyebaran ilmu pengetahuan, perpustakaan Dar Al-Hikmah terus mengalami perkembangan, baik dari segi fasilitas maupun fungsi perpustakaan sebagai wadah ilmu pengetahuan. Syalabi ${ }^{58}$ menjelaskan bahwa Al-Hakim membangun perpustakaan Dar Al-Hikmah sebagai lembaga untuk penyebaran ilmu pengetahuan yang dilengkapi beberapa pengajar. Dalam proses belajar-mengajar, ia mengangkat ahli baca al-Qur'an, fukaha, astrolog, ahli tata bahasa, dan dokter. Dari penjelasan tersebut dapat dilihat bahwa Al-Hakim menjadikan perpustakaan sebagai wadah untuk belajar, terlepas dari prinsipnya yang menempatkan perpustakaan Dar Al-Hikmah sebagai upaya penyebaran ajaran Syi'ah ekstrem di kalangan masyarakatnya yang kebanyakan Suni. Bahkan, dalam proses belajar-mengajar sebagaimana dijelaskan Hitti, perpustakaan Dar Al-Hikmah memiliki kurikulum yang meliputi kajian ilmu keislaman, astronomi, dan kedokteran. ${ }^{59}$

Shadily dalam Samsuddin ${ }^{60}$ menjelaskan bahwa perkembangan perpustakaan Dar Al-Hikmah yang ada di Mesir cukup pesat. Karena dukungan raja, fasilitas lembaga ini lengkap, seperti tersedianya ruang baca yang digunakan sebagai tempat pertemuan ahlul hadist, hukum, tata bahasa, kedokteran, astronomi, logika, dan ahli matematika. Lembaga yang diatur Da'i Ad-Du'at ini pada hari-hari tertentu mengundang cendekiawan untuk mengadakan pertemuan rutin. Perpustakaan tidak hanya menerapkan proses belajar-mengajar tetapi juga diskusi rutin. Hal ini senada dengan penjelasan Zaidan dalam Syalabi ${ }^{61}$ bahwa AlHakim selaku khalifah Daulah Fatimiyah yang menjadi pelopor berdirinya perpustakaan Dar Al-Hikmah memfasilitasi pengunjung perpustakaan, baik untuk

\footnotetext{
${ }^{58}$ Syalabi, Ahmad. Sejarah Pendidikan Islam (Jakarta: Bulan Bintang, 1973).

${ }^{59}$ Hitti, Philip K. History of the Arabs. Terj. Cecep Lukman Yasin dan Dedi Slamet Riyadi. (Jakarta: Serambi Ilmu Semesta, 2002).

${ }^{60}$ Samsuddin. "Institusi Pendidikan Islam (eksistensi perpustakaan darul himah / darul ilmi dan upaya pengembangannya dalam konteks kekinian", dalam Jurnal Al-Kuttab, Vol.1, No. 1 (Juni 2013). Diakses dalam ejournal.perpustakaanstainpsp.net>pdf_1 pada tanggal 17 Juli 2017 pukul 13.28 WIB.

${ }^{61}$ Syalabi, Ahmad. Sejarah Pendidikan Islam (Jakarta: Bulan Bintang, 1973).
} 
membaca buku dan belajar, maupun untuk diskusi. Akhirnya, diskusi pada masa itu marak.

Juga, Rahim dan Hasan dalam Karim menjelaskan bahwa perpustakaan Dar Al-Hikmah yang didirikan pada tahun $1005 \mathrm{M}$ dapat dikatakan sejajar dengan lembaga-lembaga ilmu pengetahuan di Cordova, Baghdad, dan lainnya. Perpustakaan Dar Al-Hikmah berhasil melahirkan banyak ilmuwan pada masanya. ${ }^{62}$ Menurut Samsuddin, perpustakaan Dar Al-Hikmah dikategorikan sebagai sebuah akademi atau perguruan tinggi meskipun tidak ditemukan rencana pengajaran berbasis kurikulum yang khusus secara reguler ataupun jadwal pelajaran sebagaimana layaknya sistem sekolah saat ini. Oleh karena itu, lembaga ini tampaknya tidak lebih dari perpustakaan megah yang terbuka untuk umum dengan fasilitas relatif lumayan. ${ }^{63}$

Samsuddin juga memparkan bahwa perpustakaan Dar Al-Hikmah merupakan pusat studi Islam, yang pengunjungnya mayoritas dari ilmuan Muslim. Mereka melakukan proses Islamisasi ilmu pengetahuan melalui penerjemahan buku-buku berbahasa asing ke dalam Bahasa 'Arab. Proses ini membantu mewujudkan misi perpustakaan Dar Al-Hikmah dalam membangkitkan ruh Islam sebagai sentralisasi pengembangan dan transmisi ajaran Islam, tempat pengkaderan umat Islam, wadah pemersatu antara ulama dan umara serta umat Islam yang semakin pluralistik, pusat kebudayaan untuk melakukan penelitian, studi, diskusi, dan simposium. ${ }^{64}$

Sejak kehadiran perpustakaan Dar Al-Hikmah sebagai pusat keilmuan dalam berbagai bidang lahir sistem belajar-mengajar (pembelajaran) di perpustakaan. Pusat keilmuan dan pembelajaran tersebut melahirkan beberapa ilmuwan yang ahli dalam berbagai bidang yang berperan sejak masa khalifah Daulah Fatimiyah pertama hingga Al-Hakim. Ilmuwan tersebut, di antaranya, adalah sebagai berikut:

\footnotetext{
${ }^{62}$ Karim, M. Abdul. Sejarah Pemikiran dan Peradaban Islam (Yogyakarta: Pustaka Book Publisher, 2009)

${ }^{63}$ Samsuddin. "Institusi Pendidikan Islam (eksistensi perpustakaan darul himah / darul ilmi dan upaya pengembangannya dalam konteks kekinian”, dalam Jurnal Al-Kuttab, Vol.1, No. 1 (Juni 2013). Diakses dalam ejournal.perpustakaanstainpsp.net>pdf_1 pada tanggal 17 Juli 2017 pukul 13.28 WIB.

${ }^{64}$ Ibid.
} 
a. Ali ibn Yunus

Menurut Hitti, Ali ibn Yunus merupakan astronom paling hebat yang pernah dilahirkan di Mesir. ${ }^{65}$ Sementara, Heriyanto memaparkan bahwa Ali ibn Yunus adalah seorang fisikawan dan astronom handal, di samping sebagai seorang ahli matematika yang berbakat. ${ }^{66}$ Sayyed Hossein Nasr dalam Heriyanto menyebutkan bahwa Ali ibn Yunus ini adalah orang pertama yang menelaah gerak isometris sebuah pendulum, sebuah penelitian yang kemudian menuju kepada konstruksi jam mekanis. ${ }^{67}$

b. Abu Ali al-Hasan ibn al-Haitsam

Hitti menjelaskan Abu Ali al-Hasan ibn al-Haitsam sebagai ilmuwan yang ahli dalam bidang ilmu fisika dan optik. Dari kecemerlangannya tersebut lahir karya-karya penting dan karya terbesarnya, yakni Kitab alManazhir (ilmu optik). ${ }^{68}$ Sunanto menjelaskan bahwa Ibn Haitsam di Barat disebut Alhazen. Karyanya yakni Kitab al-Manazhir diterjemahkan ke dalam bahasa Latin di masa Gerard of Cremona dan disiarkan tahun 1572. George Sarton (ahli sejarah dari Harvard University) menyebut Ibn Haitsam fisikawan Muslim terbesar dan salah seorang ilmuwan optik terbesar sepanjang zaman. ${ }^{69}$

c. Ammar ibn Ali al-Maushili

Menurut Hitti menyatakan bahwa Ammar ibn Ali al-Maushili menulis karya penting yang lebih orisinil dari Tadzkirah karya Ibn Isa (ilmuwan lain semacam dengannya), yakni al-Muntakhab fi ilaj al-'ayn (penyembuhan mata). Karya Ammar tersebut menjadi standar dalam disiplin penyakit mata 'optalmologi'. Ia menemukan dasar-dasar operasi katarak yang belum parah dengan menghisapnya melalui lubang pembuluh. ${ }^{70}$

\footnotetext{
${ }^{65}$ Hitti, Philip K. History of the Arabs. Terj. Cecep Lukman Yasin dan Dedi Slamet Riyadi. (Jakarta: Serambi Ilmu Semesta, 2002).

${ }^{66}$ Heriyanto, Husein. Menggali Nalar Saintifik Peradaban Islam. Jakarta: Mizan Publika, 2011)

${ }^{67}$ Ibid.

${ }^{68}$ Hitti, Philip K. History of the Arabs. Terj. Cecep Lukman Yasin dan Dedi Slamet Riyadi. (Jakarta: Serambi Ilmu Semesta, 2002).

${ }^{69}$ Sunanto, Musyrifah. Sejarah Islam Klasik: perkembangan ilmu pengetahuan Islam (Jakarta: Kencana, 2003: I44-5)

${ }^{70}$ Hitti, Philip K. History of the Arabs. Terj. Cecep Lukman Yasin dan Dedi Slamet Riyadi. (Jakarta: Serambi Ilmu Semesta, 2002).
} 
d. Syaikh Imam Ibrahim al-Barmawi

Amaliyah dalam Jurnal Lentera Pendidikan menjelaskan bahwa Syaikh Imam Ibrahim al-Barmawi adalah ahli dalam bidang ilmu syariah dan bahasa. $^{71}$

e. Syaikh Muhammad Abbasi al-Mahdi al-Hanafi

Amaliyah dalam Jurnal Lentera Pendidikan menjelaskan bahwa Syaikh Muhammad Abbasi al-Mahdi al-Hanafi berperan dalam pembaharuan sistem ujian yang ditempuh peserta didik, seperti dalam ujian untuk mendapatkan ijazah AL-Azhar. ${ }^{72}$

f. Syaikh Muhammad Abduh

Amaliyah dalam Jurnal Lentera Pendidikan menjelaskan bahwa Syaikh Muhammad Abduh termasuk pembaharu agama dan sosial di Mesir. ${ }^{73}$

g. Ali bin Nu'man

Al-Maqrizi dalam Sayyid menguraikan bahwa Ali bin Nu'man adalah seorang hakim Daulah Fatimiyah yang ahli dalam bidang ilmu hukum. ${ }^{74}$ Amin mengutarakan bahwa an-Nu'man dan beberapa keturunannya menduduki jabatan Qadhi dan keagamaan tertinggi selama 50 tahun sejak penakhlukan Mesir sampai pada masa pemerintahan Al-Hakim. Para Qadhi ini tidak hanya pandai dalam bidang hukum, tetapi juga cakap dalam berbagai disiplin pendidikan tinggi. ${ }^{75}$

h. Ibnu Killis

Selain mengemban amanah sebagai wazir, seperti dijelaskan Amin, ia juga memberikan perhatian terhadap pengajaran. ${ }^{76}$

i. Muhammad At-Tamim

Amin menerangkan bahwa Muhammad At-Tamim adalah seorang fisikawan besar. ${ }^{77}$

j. Al-Kindi

\footnotetext{
${ }^{71}$ Amaliyah, Asriati. "Eksistensi Pendidikan Islam di Mesir Masa Daulah Fatimiyah: lahirnya Al-Azhar, tokoh-tokoh pendidikan pada masa daulah" dalam Jurnal Lentera Pendidikan, 2013.

72 Ibid.

73 Ibid.

${ }^{74}$ Sayyid, Aiman Fuad. Al-Dawlah al-Fathimiyyah fi Mishr Tafsir Jadid (Kairo: Al-Dar AlMasriyah lil-Bananiyah, 1992).

75 Amin, Samsul Munir. Sejarah Peradaban Islam (Jakarta: Amzah, 2009:267).

76 Ibid.

${ }^{77}$ Ibid.
} 
Menurut Amin, Al-Kindi merupakan seorang sejarawan dan topographer terbesar yang hidup di Fustat dan meninggal tahun 961 M. $^{78}$

Selanjutnya, rangakaian proses pembangunan perpustakaan Dar AlHikmah sebagai wadah ilmu pengetahuan yang mendukung tradisi keilmuan, yakni adanya belajar-mengajar, mampu melahirkan ilmuwan dan tokoh penting pada masa Daulah Fatimiyah. Ini merupakan suatu pencapaian yang menjadi salah satu bukti bahwa Al-Hakim berhasil membawa Daulah Fatimiyah menuju puncak keberhasilan dalam kemajuan ilmu pengetahuan. Berawal dari masa Al-Hakim, tradisi keilmuan terus berkembang. Hal tersebut merupakan suatu warisan intelektual yang sangat penting bagi pemimpin setelahnya.

Uraian di atas menjadi kebanggaan bagi masyarakat Mesir karena ilmu pengetahuan melahirkan banyak manfaat. Lembaga perpustakaan mendorong aktivitas belajar-mengajar, diskusi, dan tempat berkumpul para ilmuwan Muslim dari berbagai daerah. Perlu diketahui bahwa, menurut Syalabi, ${ }^{79}$ pengajaran di Mesir pada masa pemerintahan Daulah Fatimiyah memiliki corak tersendiri dan condong kepada suatu arah tertentu, yaitu menyiarkan Madzhab Isma'ili yang dianut para khalifah. Penyiaran Madzhab tersebut serta propagandanya telah menempuh garis-garis baru yang belum pernah dikenal sebelumnya di daerah itu. Akhirnya, terjadilah perubahan pada masalah-masalah pokok yang menjadi objek studi dan sistem-sistemnya. Kedua masalah tersebut masih saja belum begitu jelas lantaran negeri Islam telah kehilangan banyak buku-buku yang dikarang oleh pemimpin-pemimpin kaum Syiah itu. Buku-buku tersebut pada umumnya hilang oleh umat Islam yang menganut Madzhab Sunni karena mereka berpendapat bahwa apa yang dikemukakan buku-buku tersebut merupakan penyelewengan dari ajaran agama yang benar yang dianut mereka. Di samping itu, buku-buku Madzhab Isma'ili yang masih ada pun sebagian besarnya berada di tangan pemuka mereka yang tidak mau mencetak dan menyiarkannya. Mereka berpendapat bahwa buku-buku tersebut ditulis hanyalah untuk orang-orang tertentu saja, bukan untuk masyarakat umum.

\footnotetext{
${ }^{78}$ Ibid.

${ }^{79}$ Syalabi, Ahmad. Sejarah Pendidikan Islam (Jakarta: Bulan Bintang, 1973).
} 
Dari argumentasi di atas pada dasarnya Daulah Fatimiyyah memiliki buku-buku langka yang merupakan kekayaan Daulah Fatimiyah. Namun, perbedaan antara Syi'ah dan Sunni menjadi salah satu kontribusi hilangnya bukubuku kaum Syi'ah tersebut. Hal ini bisa menjadi wajar karena pada masa Daulah Fatimiyah, khususnya saat kepemimpinan Al-Hakim, batasan terhadap aliran selain Syi'ah sangat ketat. Pada masa Al-Hakim, kaum Syi'ah mendapatkan tempat tertinggi di antara kelompok Islam lainnya, seperti Sunni. Pengajaran dan asas yang dibangun di Perpustakaan Dar Al-Hikmah adalah untuk menyebarkan aliran Syi'ah ekstrem. Terlepas dari penyebaran aliran Syi'ah ektrem tersebut, perpustakaan Dar Al-Hikmah mampu memberikan manfaat yang tidak hanya terbatas pada hal tersebut, tetapi juga mencakup berbagai bidang ilmu pengetahuan lainnya. Tidak mengherankan jika perpustakaan Dar Al-Hikmah menjadi salah satu perpustakaan yang megah dengan segala fasilitas dan ilmu pengetahuan yang dihimpun di dalamnya.

Pengajaran berbasis Syi'ah tersebut pun tampak semakin jelas berdasarkan pendapat Bardy dalam Syalabi ${ }^{80}$ bahwa pada mulanya Al-Hakim hendak menarik perhatian masyarakat untuk berkunjung ke perpustakaan Dar AlHikmah dengan memberikan gambaran seolah-olah perpustakaan tersebut disediakan untuk studi bebas dalam semua madzhab, lalu diundang juga guruguru dari kalangan Ahlus Sunnah dan kaum Syi'ah dan dibacakannya keutamaankeutamaan para sahabat. Namun tidak lama kemudian, ia segera menyingkirkan guru-guru kaum Ahlus Sunnah itu, bahkan ia membunuh sebagian dari mereka. Dengan demikian, jelas kecenderungan perpustakaan Dar Al-Hikmah kepada Madzhab Isma'iliyah. Fasilitas-fasilitas yang disediakan perpustakaan Dar AlHikmah untuk para pelajar menyebabkan perpustakaan tersebut muncul sebagai tempat yang paling menonjol bagi propaganda madzhab yang dianut secara resmi oleh mereka. Perpustakaan Dar Al-Hikmah juga digunakan sebagai tempat pertemuan para propagandis besar dengan para ahli-ahli dakwah dan ahli-ahli fiqih untuk mengatur urusan-urusan dakwah mereka.

\footnotetext{
${ }^{80}$ Ibid.
} 
Terlepas dari argumentasi tersebut, peneliti menyimpulkan bahwa perpustakaan Dar Al-Hikmah tetap memiliki peran besar dalam khazanah keilmuan, meskipun keilmuan yang diajarkan dalam perpustakaan tersebut cenderung mengarah pada ajaran Syi'ah. Al-Hakim sebagai khalifah pada masa itu tidak membatasi pengembangan berbagai bidang ilmu pengetahuan di perpustakaan. Hal tersebut tentu menjadi suatu kemajuan bangsa Mesir dalam bidang ilmu pengetahuan yang juga memberi pengaruh dalam kemajuan bidang pengajaran dan keilmuan bangsa Mesir saat itu.

\section{KESIMPULAN}

Berdasarkan hasil pembahasan di atas dapat disimpulkan bahwa Khalifah Al-Hakim Biamrillah memainkan beberapa peran dalam perkembangan perpustakaan Dar Al-Hikmah di Mesir tahun 996-1021 M yang dapat dilihat dalam beberapa poin penting, yaitu: pertama, perpustakaan Dar Al-Hikmah dikelola tenaga profesional yang terdiri dari kepala dan staf perpustakaan. Tugas pengelola perpustakaan tersebut melakukan shelving, klasifikasi dan katalogisasi, menurun (menyalin) buku, menjilid buku, dan preservasi buku. Juga, ada pegawai, pekerja, dan khadam yang membantu mengelola perpustakaan dalam melayani pengunjung perpustakaan. Kedua, pengembangan koleksi di perpustakaan Dar Al-Hikmah mengutamakan kelengkapan koleksi dilakukan dengan cara pembelian. Juga, melakukan perawatan koleksi untuk perbaikan buku yang rusak dan robek. Terakhir, sebagai pusat ilmu pengetahuan dan pembelajaran, perpustakaan Dar Al-Hikmah memiliki aktifitas belajar-mengajar termasuk penyediaan pengajar dan kurikulum. Juga, lahir para ilmuwan yang berpengaruh besar pada masa itu. Di antaranya, Ali ibn Yunus dikenal sebagai astronom paling hebat yang pernah dilahirkan di Mesir; juga, Abu Ali al-Hasan ibn al-Haitsam sebagai ilmuwan yang ahli dalam bidang ilmu fisika dan optik serta ilmuan-ilmuan lainnya yang tak kalah hebatnya. 


\section{DAFTAR PUSTAKA}

Abdullah, Taufiq. Ensiklopedi Tematis Dunia Islam. (Jakarta: Ichtiar Baru Van Houve. 2002)

Abdurrahman, Dudung. Metode Penelitian Sejarah. (Jakarta: Logos Wacana Ilmu, 1999)

Abdurrahman, Dudung. Metodologi Penelitian Sejarah. (Yogyakarta: Ar-Ruzz Media, 2007)

Amal, Taufik Adnan. Rekonstruksi Sejarah Al-Qur'an. (Ciputat: Pustaka Alvabet, 2003)

Amaliyah, Asriati. 2013. "Eksistensi Pendidikan Islam di Mesir Masa Daulah Fatimiyah: lahirnya Al-Azhar, tokoh-tokoh pendidikan pada masa daulah fatimiyah dan pengaruhnya terhadap dunia Islam", dalam Jurnal Lentera Pendidikan, nomor. 1. Tahun 2013. Vol. 16 Juni. Diakses dalam http://www.google.co.id/amp/docplayer.info/amp/74221-Kata-kuncidaulah-fatimiyah-pendidikan-islam-al-azhar.html pada tanggal 3 Mei 2017 pukul 10.55 WIB.

Amin, Samsul Munir. Sejarah Peradaban Islam. (Jakarta: Amzah, 2009)

Burke, Peter. Sejarah dan Teori-teori Sosial. Terj. Mestika Zed dan Zulhami. (Jakarta: Yayasan Obor Indonesia, 2001)

Cohen, Bruce J. Sosiologi Suatu Pengantar. (Jakarta: Rineka Cipta, 1992)

Hasan, Masudul. History of Islam. Vol. 1. (Delhi: Adam Publisher and Distributers, 1995)

Heriyanto, Husein. Menggali Nalar Saintifik Peradaban Islam. (Jakarta: Mizan Publika, 2011)

Hitti, Philip K. History of the Arabs. Terj. Cecep Lukman Yasin dan Dedi Slamet Riyadi. (Jakarta: PT Serambi Ilmu Semesta, 2002)

Hitti, Philip K. History of the Arabs. Terj. Cecep Lukman Yasin dan Dedi Slamet Riyadi. (Jakarta: PT Serambi Ilmu Semesta, 2008)

Imamuddin, S.M. Some Leading Muslim Libraries of the World. (Dhaka: Islamic Foundation Bangladesh, 1983)

Karim, M. Abdul. Sejarah Pemikiran dan Peradaban Islam. (Yogyakarta: Pustaka Book Publisher, 2009)

Karim, M. Abdul. Sejarah Pemikiran dan Peradaban Islam. (Yogyakarta: Bagaskara, 2012)

Kuntowijoyo. Pengantar Ilmu Sejarah. (Yogyakarta: Yayasan Bentang Budaya, 1995)

Lasa Hs. Kamus Kepustakawanan Indonesia. (Yogyakarta: Pustaka Book Publisher, 2009) 
Mackensen, Ruth Stellhorn. 1936. "Background of the History of Muslim Libraries". dalam The American Journal of Semitic Language and Literatures, Vol. 52 (Oktober-July).

Mahasnah, Muhammad Husain. Pengantar Studi Sejarah Peradaban Islam. (Jakarta: Pustaka al Kautsar, 2016)

Qalyubi, Syihabuddin dkk. Dasar Ilmu Perpustakaan dan Informasi. (Yogyakarta: Jurusan Ilmu Perpustakaan dan Informasi Fakultas Adab dan Ilmu Budaya UIN Sunan Kalijaga, 2007)

Rifai, Agus. Perpustakaan Islam: konsep, sejarah, dan kontribusinya dalam membangun peradaban Islam masa klasik. (Jakarta: Rajawali Press, 2013)

Samsuddin. 2013. "Institusi Pendidikan Islam (eksistensi perpustakaan darul himah / darul ilmi dan upaya pengembangannya dalam konteks kekinian", dalam Jurnal Al-Kuttab, Vol.1, No. 1 (Juni 2013). Diakses dalam e-journal.perpustakaanstainpsp.net>pdf_1 pada tanggal 17 Juli 2017 pukul 13.28 WIB.

Sayyid, Aiman Fuad. al-Dawlah al-Fathimiyyah fi Mishr Tafsir Jadid. (Kairo: AlDar Al-Masriyah lil-Bananiyah, 1992)

Soekanto, Soerjono. Sosiologi Suatu Pengantar. (Jakarta: PT. Raja Grafindo Persada, 1990)

Sunanto, Musyrifah. Sejarah Islam Klasik: perkembangan ilmu pengetahuan Islam. (Jakarta: Kencana, 2003)

Sutarno NS, Manajemen Perpustakaan: suatu pendekatan praktik. (Jakarta: Sagung Seto, 2006)

Syaefudin, Machfud. Dinamika Peradaban Islam: perspektif historis. (Yogyakarta: Pustaka Ilmu, 2006)

Syalabi, Ahmad. Sejarah Pendidikan Islam. (Jakarta: Bulan Bintang, 1973)

Yatim, Badri. Sejarah Peradaban Islam. (Jakarta: Raja Grafindo Persada, 2006)

Yulia, Yuyu dan Janti G. Sujana. Materi Pokok Pengembangan Koleksi. (Jakarta: Universitas Terbuka, 2009)

Zuhairini. Sejarah Pendidikan Islam. (Jakarta: Bumi Aksara, 1986) 